\title{
Cobalt/Nickel Double Oxides Prepared by Two Methods Exhibiting Supercapacitive Performances
}

\author{
Dongxia An, Yu Zhang, Meigui Feng, Hong Zhang, Gang Ma, Cuimiao Zhang, Zhiguang Ma*
}

College of Chemistry and Environmental Science, Hebei University, Baoding, China

Email address:

hxymzg@163.com (Zhiguang Ma)

${ }^{*}$ Corresponding author

\section{To cite this article:}

Dongxia An, Yu Zhang, Meigui Feng, Hong Zhang, Gang Ma, Cuimiao Zhang, Zhiguang Ma. Cobalt/Nickel Double Oxides Prepared by Two Methods Exhibiting Supercapacitive Performances. Nanoscience and Nanometrology. Vol. 4, No. 1, 2018, pp. 1-8.

doi: $10.11648 /$ j.nsnm.20180401.11

Received: May 10, 2018; Accepted: July 9, 2018; Published: August 7, 2018

\begin{abstract}
Two different three-dimensional nanostructured cobalt/nickel layered double oxides grown on Ni foam (NF) were synthesized through one-step $\left(\mathrm{NF} / \mathrm{NiCo}_{2} \mathrm{O}_{4}\right)$ and two-step $\left(\mathrm{NF} / \mathrm{Co}_{3} \mathrm{O}_{4} / \mathrm{NiO}\right)$ solvothermal method for flexible and high performance supercapacitor applications. The as-prepared composites have been systematically characterized by powder X-ray diffraction, scanning electron microscopy, and Brunauer-Emmett-Teller analysis. The pseudocapacitive performances of composite electrode materials were investigated by the electrochemical tests. Cyclic voltammetry (CV), Galvanostatic chargedischarge (GCD) and Electrochemical impedance spectra (EIS) were performed using workstation. When the current density is 1 $\mathrm{A} / \mathrm{g}$, the capacitance of $\mathrm{NF} / \mathrm{Co}_{3} \mathrm{O}_{4} / \mathrm{NiO}$ electrode material is $992 \mathrm{~F} / \mathrm{g}$; the capacitance of $\mathrm{NF} / \mathrm{NiCo}_{2} \mathrm{O}_{4}$ is $239 \mathrm{~F} / \mathrm{g}$. And the retention of $\mathrm{NF} / \mathrm{NiCo}_{2} \mathrm{O}_{4}$ electrode is $93.8 \%$ after 2000 cycles. From this comparison, it could see that the $\mathrm{NF} / \mathrm{Co}_{3} \mathrm{O}_{4} / \mathrm{NiO}$ electrode exhibits more than four times higher specific capacitance at a current density of $1 \mathrm{~A} / \mathrm{g}$, good capacitance retention and excellent cycling stability than $\mathrm{NF} / \mathrm{NiCo}_{2} \mathrm{O}_{4}$ electrode. Furthermore that the specific capacitance of $\mathrm{NF} / \mathrm{Co}_{3} \mathrm{O}_{4} / \mathrm{NiO}$ electrode increases after testing for 2000 cycles. And it can see the comparison between the interfacial charge transfer resistance (Rct) (occurring at the electrode/electrolyte interface and double layer capacitance caused by Faradaic reactions) and Warburg resistance (W), (corresponding to the ion diffusion in the host material diffusive resistance of the electrolyte in the electrode surface). The Nyquist plots are characteristic of being able to separate the charge transfer resistance and series resistance directly. However it is evident that the Nyquist plot of $\mathrm{NF} / \mathrm{Co}_{3} \mathrm{O}_{4} / \mathrm{NiO}$ electrode is higher than that of $\mathrm{NF} / \mathrm{NiCO}_{2} \mathrm{O}_{4}$ and $\mathrm{NF} / \mathrm{Co}_{3} \mathrm{O}_{4}$ electrodes, demonstrating the Rct and Warburg resistance (W) of $\mathrm{NF} / \mathrm{Co}_{3} \mathrm{O}_{4} / \mathrm{NiO}$ electrode is higher. The comprehensive test results show that the $\mathrm{NF} / \mathrm{Co}_{3} \mathrm{O}_{4} / \mathrm{NiO}$ coreshell nanostructure arrays with remarkable electrochemical properties could be considered as potential electrode materials for next generation supercapacitors in high energy density storage systems.
\end{abstract}

Keywords: Cobalt/Nickel Layered Double Oxides, Hydrothermal Method, Supercapacitor

\section{Introduction}

With the depletion of fossil fuels and aggravating of environmental pollution, the need for novel and clean energy sources become increasing. Renewable clean energy technologies, such as ocean, solar and wind energy, typically require effective storage devices for both alternative energy source and transportation of electricity [1,2]. Supercapacitors have become a hot research due to its high power density, fast charge/discharge rate, long cycle life, environmental safety and superior properties at a low temperature $[3,4]$.
Supercapacitors are divided into electric double layer capacitors (EDLCs) [5, 6] and pseudocapacitors [7-9], owing to their different energy storage mechanisms. EDLCs store energy in the electrical double layer of electrode/electrolyte interface. Porous carbon-based materials (e.g. activated carbon, carbon tube and graphene) are well-known as electric double layer capacitance materials. Pseudocapacitors, which store energy by rapid Faradic redox reaction of electrode materials [10], the materials included transition metal oxides 
and hydroxides [11], conducting polymer [12], etc.

Transition metal oxides, as an electrode material of supercapacitors, have drawn more attention of scientists due to their higher Faradic pseudocapacitance than electric double layer capacitance of carbon-based materials. They include $\mathrm{Co}_{3} \mathrm{O}_{4}$ [13-16], $\mathrm{NiO}[17,18], \mathrm{MnO}_{2}\left[19-24 \mathrm{Fe}_{3} \mathrm{O}_{4}\right.$ [25] and $\mathrm{V}_{2} \mathrm{O}_{5}$ [26]. Owing to nickel oxide's high theoretical capacitance (about $2573 \mathrm{~F} / \mathrm{g}$ ) and cobalt oxide's high redox activity and reversibility [27], $\mathrm{Co}_{3} \mathrm{O}_{4} / \mathrm{NiO}$ composite electrode [28-31] is often assembled and the electrochemical properties are widely investigated. It was also observed that the double metal oxide $\mathrm{Co}_{3} \mathrm{O}_{4}-\mathrm{NiO}$ can combine the advantages of both cobalt and nickel oxides and has superiority over either of the single oxides in chemical-looping combustion [32]. Recently, mixed transition metal oxides have attracted wide attention owing to their higher conductivity, more reactive sites based on different metal ions, complex composition and the synergetic effects of multiple metal species [33-38]. $\mathrm{NiCo}_{2} \mathrm{O}_{4}$ is also popular as an electrode material since it provides many attractive properties of rich electroactive centrals, low-cost, abundant resources and environmentally friendly [39, 40]. However, the electrical conductivity of $\mathrm{NiCo}_{2} \mathrm{O}_{4}$ still needs to improve to achieve full electrode material utilization, higher rate capability and faster discharge/charge rates [33].

In this paper, it produced different morphology (cobalt and nickel) mixed oxides on the Ni foam by a general and low cost solvothermal synthesis method, and its electrochemical performance was investigated by the cyclic voltammetry, galvanostatic charge-discharge and electrochemical impedance spectroscopy measurements. However, the mixed oxides exhibit different structure and electrochemical performances. The $\mathrm{NF} / \mathrm{NiCo}_{2} \mathrm{O}_{4}$ synthesized by one-step solvothermal shows more lower specific capacitance than the $\mathrm{NF} / \mathrm{Co}_{3} \mathrm{O}_{4} / \mathrm{NiO}$ synthesized by two-step solvothermal. In addition, cycling stabilities of both samples are distinct. The specific capacitance of $\mathrm{NF} / \mathrm{Co}_{3} \mathrm{O}_{4} / \mathrm{NiO}$ electrode increases after testing for 2000 cycles, the retention of $\mathrm{NF} / \mathrm{NiCo}_{2} \mathrm{O}_{4}$ electrode is $93.8 \%$ after 2000 cycles.

\section{Experimental}

\subsection{Synthesis of Cobalt/Nickel Layered Double Oxides}

All reagents in the experiment were of analytical grade and directly used without any purification. Prior to the synthesis, $\mathrm{Ni}$ foam $(1 \mathrm{~cm} \times 1 \mathrm{~cm}$ in square shape) was cleaned by sonication to remove the possible surface substance, the sonication was carried out in acetone, dilute hydrochloric acid, ultrapure water and absolute ethanol for $15 \mathrm{~min}$ each, respectively.

One-step synthesis method: $4.0 \mathrm{mmol} \mathrm{Co}\left(\mathrm{NO}_{3}\right)_{2} \cdot 6 \mathrm{H}_{2} \mathrm{O}, 2.0$ mmol Ni $\left(\mathrm{NO}_{3}\right)_{2} \cdot 6 \mathrm{H}_{2} \mathrm{O}$ and $2 \mathrm{~g}$ urea were dissolved in $50 \mathrm{~mL}$ of ultrapure water under constant magnetic stirring to form a homogeneous solution. After that, the obtained solution was transferred into a $100 \mathrm{~mL}$ Teflon-lined stainless steel autoclave.
And the pre-cleaned $\mathrm{Ni}$ foam was immersed into the above aqueous solution. Next, the autoclave maintained at $120^{\circ} \mathrm{C}$ for $3 \mathrm{~h}$ and then allowed to cool down room temperature spontaneously. The precipitate product and hydroxides-coated $\mathrm{Ni}$ foam were washed with ultrapure water and ethanol for several times. Finally, the precipitate product dried at $60^{\circ} \mathrm{C}$ in vacuum for $12 \mathrm{~h}$, and then the precipitate and hydroxides-coated $\mathrm{Ni}$ foam were annealed at $300^{\circ} \mathrm{C}$ in air for $2 \mathrm{~h}$ to get $\mathrm{NiCo}_{2} \mathrm{O}_{4}$ and $\mathrm{NiCo}_{2} \mathrm{O}_{4}$-coated $\mathrm{Ni}$ foam $\left(\mathrm{NF} / \mathrm{NiCO}_{2} \mathrm{O}_{4}\right)$.

Two-step synthesis method: First, $4.0 \mathrm{mmol}$ Co $\left(\mathrm{NO}_{3}\right)_{2} \cdot 6 \mathrm{H}_{2} \mathrm{O}$ and $1 \mathrm{~g}$ urea were dissolved in $50 \mathrm{~mL}$ of ultrapure water under constant magnetic stirring to form a homogeneous pink solution, and then the solution was transferred to a $100 \mathrm{~mL}$ Teflon-lined stainless steel autoclave. The $\mathrm{Co}_{3} \mathrm{O}_{4}$ and $\mathrm{NF} / \mathrm{Co}_{3} \mathrm{O}_{4}$ were prepared by a similar route as for $\mathrm{NiCo}_{2} \mathrm{O}_{4}$ and $\mathrm{NF} / \mathrm{NiCo}_{2} \mathrm{O}_{4}$. Next, $2.0 \mathrm{mmol} \mathrm{Ni}$ $\left(\mathrm{NO}_{3}\right)_{2} \cdot 6 \mathrm{H}_{2} \mathrm{O}$ and $1 \mathrm{~g}$ urea were dissolved in $50 \mathrm{~mL}$ of ultrapure water. After stirring for $30 \mathrm{~min}$, the solution was transferred to a $100 \mathrm{~mL}$ Teflon-lined stainless steel autoclave. The $\mathrm{NF} / \mathrm{Co}_{3} \mathrm{O}_{4}$ was immersed into the solution. Finally, the $\mathrm{Ni}$ $(\mathrm{OH})_{2}$ was prepared and coated on the $\mathrm{NF} / \mathrm{Co}_{3} \mathrm{O}_{4}$ through the same way for $\mathrm{NiO}$ and $\mathrm{NiO}$-coated $\mathrm{NF} / \mathrm{Co}_{3} \mathrm{O}_{4}$. (noted as $\mathrm{NF} / \mathrm{Co}_{3} \mathrm{O}_{4} / \mathrm{NiO}$ ).

\subsection{Materials Characterization}

The samples were characterized by powder X-ray diffraction (XRD, Bruker D8 Advance), field emission scanning electron microscope (SEM, JSM-7500F). $\mathrm{N}_{2}$ absorption-desorption were performed with a Micromeritics Tristar II 3020.

\subsection{Electrochemical Measurements}

The electrochemical measurements of the $\mathrm{NF} / \mathrm{NiCo}_{2} \mathrm{O}_{4}$, $\mathrm{NF} / \mathrm{Co}_{3} \mathrm{O}_{4} / \mathrm{NiO}$ and $\mathrm{NF} / \mathrm{Co}_{3} \mathrm{O}_{4}$ composites electrodes were performed in $3 \mathrm{M} \mathrm{KOH}$ using three-electrode electrochemical workstation (Interface 1000, Gamry Instruments, USA). The saturated calomel electrode (SCE) and platinum plate were used as reference and counter electrode, respectively. A series of electrochemical measurements, including cyclic voltammetry (CV), galvanostatic charge-discharge tests (GCD) and electrochemical impedance spectroscopy (EIS). The EIS measurements were carried out in the frequency range of 100 $\mathrm{kHz}$ to $0.01 \mathrm{~Hz}$ at the open circuit potentials, and the applied potential amplitude was $5 \mathrm{mV}$. The corresponding specific capacitance $(\mathrm{C})$ was calculated from the following equation:

$$
\mathrm{C}=\frac{\mathrm{I} \Delta \mathrm{t}}{\mathrm{m} \Delta \mathrm{V}}
$$

In which $\mathrm{C}$ is the specific capacitance $(\mathrm{F} / \mathrm{g}), \mathrm{I}$ is the discharge current (A), $\mathrm{t}$ is the discharge time (s), $\mathrm{V}$ is the potential window $(\mathrm{V}), \mathrm{m}$ is the mass of electro-active materials in the electrodes $(\mathrm{g})$. 


\section{Results and Discussion}

\subsection{The Structural and Morphological Characterization of Samples}

\subsubsection{XRD}

Figure 1 shows the XRD patterns of the $\mathrm{Co}_{3} \mathrm{O}_{4}, \mathrm{NiO}$ and $\mathrm{NiCO}_{2} \mathrm{O}_{4}$ samples. The patterns of $\mathrm{Co}_{3} \mathrm{O}_{4}$ are composed of seven major diffraction peak appearing at $2 \theta$ values of $19.0^{\circ}$, $31.3^{\circ}, 36.8^{\circ}, 44.8^{\circ}, 49.1^{\circ}, 59.4^{\circ}, 65.2^{\circ}$ and $77.3^{\circ}$. The patterns of as-synthesized $\mathrm{Co}_{3} \mathrm{O}_{4}$ sample could be indexed to the $\mathrm{Co}_{3} \mathrm{O}_{4}$ (PDF: 73-1701). the patterns of $\mathrm{NiO}$ are composed of four major diffraction peak appearing at $2 \theta$ values of $37.2^{\circ}, 43.3^{\circ}$, $62.8^{\circ}$ and $75.3^{\circ}$, The patterns of as-synthesized $\mathrm{NiO}$ sample could be indexed to the NiO (PDF: 73-1523). The patterns of $\mathrm{NiCo}_{2} \mathrm{O}_{4}$ are composed of seven major diffraction peak appearing at $2 \theta$ values of $18.9^{\circ}, 31.2^{\circ}, 36.7^{\circ}, 44.6^{\circ}, 48.9^{\circ}$, $59.1^{\circ}, 65.0^{\circ}$ and $77.0^{\circ}$. The patterns of as-synthesized $\mathrm{NiCo}_{2} \mathrm{O}_{4}$ sample could be indexed to the $\mathrm{NiCo}_{2} \mathrm{O}_{4}$ (PDF: 73-1702). As a result, the XRD patterns demonstrated that the samples were the combination of the crystalline $\mathrm{Co}_{3} \mathrm{O}_{4}$ and $\mathrm{NiO}$ in two-step synthesis, and the $\mathrm{NiCo}_{2} \mathrm{O}_{4}$ samples were obtained in the one-step synthesis method.

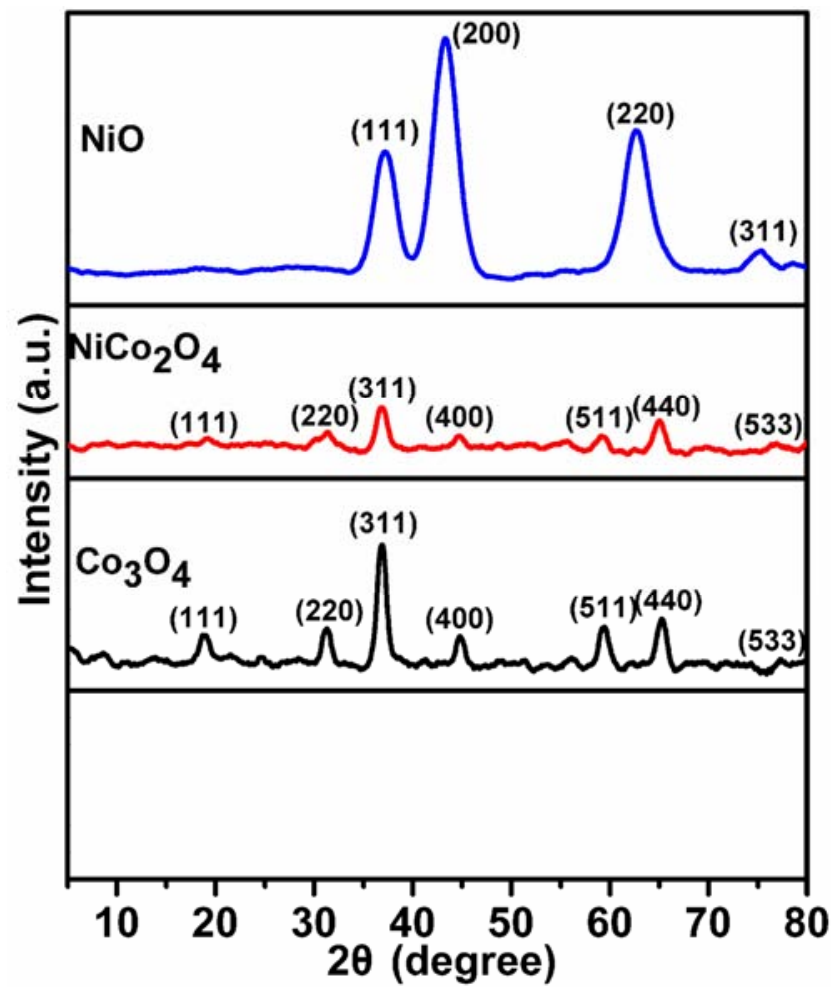

Figure 1. XRD patterns of the samples.

\subsubsection{SEM}

The SEM images of as-synthesized nickel foam, $\mathrm{NF} / \mathrm{Co}_{3} \mathrm{O}_{4}$, $\mathrm{NF} / \mathrm{Co}_{3} \mathrm{O}_{4} / \mathrm{NiO}$ and $\mathrm{NF} / \mathrm{NiCo}_{2} \mathrm{O}_{4}$ electrodes are shown in
Figure 2. Obviously, the nickel foam presents porous structure in Figure 2(a). The $\mathrm{Co}_{3} \mathrm{O}_{4}$ presents a rod-shaped polygonal appearance on the surface of NF in Figure 2(b). Then, the NiO were grown on the surface of $\mathrm{NF} / \mathrm{Co}_{3} \mathrm{O}_{4}$, the $\mathrm{NiO}$ displays flake-like construction coating on the $\mathrm{Co}_{3} \mathrm{O}_{4}$ to form a core-shell structure with higher specific surface area. Therefore, the $\mathrm{NF} / \mathrm{Co}_{3} \mathrm{O}_{4} / \mathrm{NiO}$ electrode exhibits better electrochemical performance. However, the $\mathrm{NF} / \mathrm{NiCo}_{2} \mathrm{O}_{4}$ presents a urchin-shaped structure.

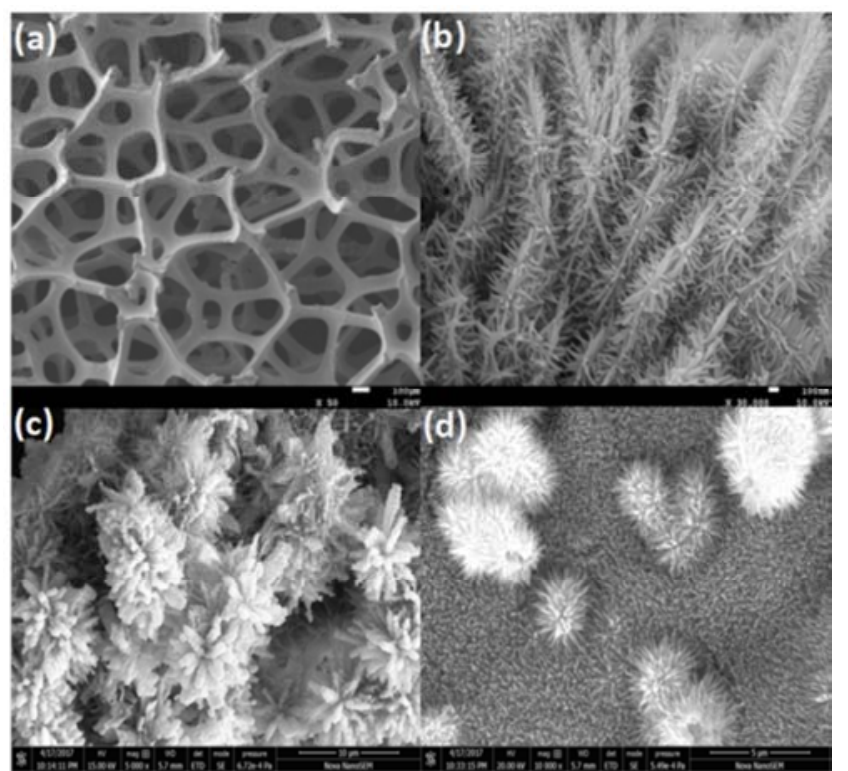

Figure 2. SEM images of the samples: (a) nickel foam, (b) $\mathrm{NF} / \mathrm{Co}_{3} \mathrm{O}_{4}$, (c) $\mathrm{NF} / \mathrm{Co}_{3} \mathrm{O}_{4} / \mathrm{NiO}$, (d) $\mathrm{NF} / \mathrm{NiCO}_{2} \mathrm{O}_{4}$.

\subsubsection{Nitrogen Adsorption-Desorption Isotherms}

The mesoporous structures and the corresponding pore size distributions metal oxide double-layer nanocompounds on nickel foam are carefully investigated by Nitrogen sorption analysis and Brunauer-Emmett-Teller (BET) method in Figure 3. The samples show a typical IV isotherm profile with distinct hysteresis loops $\left(\mathrm{P} / \mathrm{P}_{0}>0.4\right)$. The Brunauer-Emmett-Teller (BET) specific surface area for $\mathrm{Co}_{3} \mathrm{O}_{4}, \mathrm{NiO}$ and $\mathrm{NiCo}_{2} \mathrm{O}_{4}$ powders are 103.98, 193.83 and $150.72 \mathrm{~m}^{2} / \mathrm{g}$, with the total pore volume of $0.17,0.37$ and 0.31 $\mathrm{cm}^{3} / \mathrm{g}$, respectively. The surface area of the $\mathrm{NiO}$ powders is higher than that of the $\mathrm{Co}_{3} \mathrm{O}_{4}$ and $\mathrm{NiCo}_{2} \mathrm{O}_{4}$ powders. Hence, $\mathrm{Co}_{3} \mathrm{O}_{4} / \mathrm{NiO}$ exhibits the larger electro-active surface area and higher electrochemical performances. The $\mathrm{Co}_{3} \mathrm{O}_{4}, \mathrm{NiO}$ and $\mathrm{NiCo}_{2} \mathrm{O}_{4}$ powders exhibit mesoporous structure with average pore size of $5.10,5.29$ and $6.13 \mathrm{~nm}$, respectively. As a result, the mesoporous structure of $\mathrm{Co}_{3} \mathrm{O}_{4} / \mathrm{NiO}$ is beneficial for providing the electrolyte ions with more efficient transport pathways to the exterior and interior of electroactive materials, which is critical for their electrochemical behaviors [41]. 


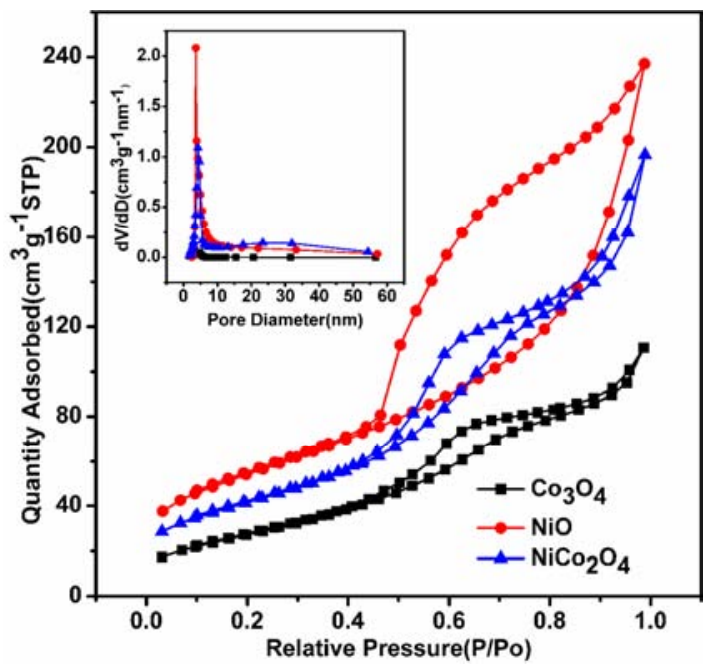

Figure 3. Nitrogen adsorption-desorption isotherms of $\mathrm{Co}_{3} \mathrm{O}_{4}, \mathrm{NiO}$ and $\mathrm{NiCO}_{2} \mathrm{O}_{4}$ on nickel foam. The inset shows its pore size distribution plot.

\subsection{Electrochemical Properties}

Figure 4 exhibits $\mathrm{CV}$ curves of $\mathrm{NF} / \mathrm{Co}_{3} \mathrm{O}_{4}, \mathrm{NF} / \mathrm{Co}_{3} \mathrm{O}_{4} / \mathrm{Ni}$ $(\mathrm{OH})_{2}, \mathrm{NF} / \mathrm{Co}_{3} \mathrm{O}_{4} / \mathrm{NiO}$ and $\mathrm{NF} / \mathrm{NiCo}_{2} \mathrm{O}_{4}$ in the voltage range of 0 to $0.5 \mathrm{~V}$ measured at a scan rate of $5 \mathrm{mV} / \mathrm{s}$. all curves of electrodes displays a pair of obvious redox peak, indicating typical pesudocapacitive properties. In addition, the enclosed area of the $\mathrm{NF} / \mathrm{Co}_{3} \mathrm{O}_{4} / \mathrm{NiO}$ electrode material is much larger than $\mathrm{NF} / \mathrm{Co}_{3} \mathrm{O}_{4}, \quad \mathrm{NF} / \mathrm{Co}_{3} \mathrm{O}_{4} / \mathrm{Ni}(\mathrm{OH})_{2}$ and $\mathrm{NF} / \mathrm{NiCo}_{2} \mathrm{O}_{4}$ electrode materials, demonstrating that the $\mathrm{NF} / \mathrm{Co}_{3} \mathrm{O}_{4} / \mathrm{NiO}$ materials have a larger capacitance than $\mathrm{NF} / \mathrm{Co}_{3} \mathrm{O}_{4}$, $\mathrm{NF} / \mathrm{Co}_{3} \mathrm{O}_{4} / \mathrm{Ni}(\mathrm{OH})_{2}$ and $\mathrm{NF} / \mathrm{NiCo}_{2} \mathrm{O}_{4}$. The improved specific capacitance for the $\mathrm{NF} / \mathrm{Co}_{3} \mathrm{O}_{4} / \mathrm{NiO}$ can be owing to the unique core-shell architecture with strong synergistic effect between $\mathrm{Co}_{3} \mathrm{O}_{4}$ and $\mathrm{NiO}$. Figure 5 and Figure 6 depict the $\mathrm{CV}$ curves of $\mathrm{NF} / \mathrm{Co}_{3} \mathrm{O}_{4} / \mathrm{NiO}$ and $\mathrm{NF} / \mathrm{NiCo}_{2} \mathrm{O}_{4}$ electrode materials at varying scan rates. The pictures display obvious redox peaks, and with increase of the scanning rate the redox current density increases, while the anodic and cathodic peaks shift toward higher and lower potentials, respectively. The phenomenon is attributed to polarization effect of the electrode.

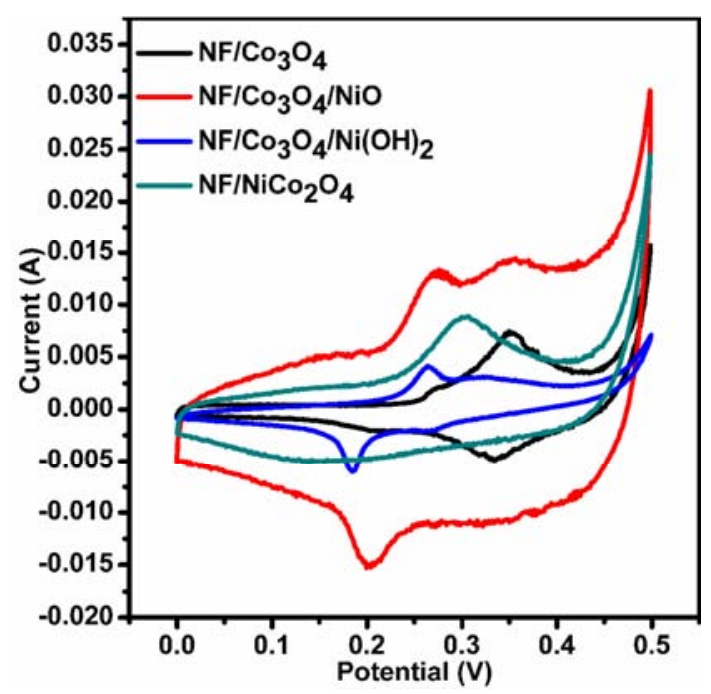

Figure 4. CV curves of the as-prepared electrodes at $5 \mathrm{mV} / \mathrm{s}$.

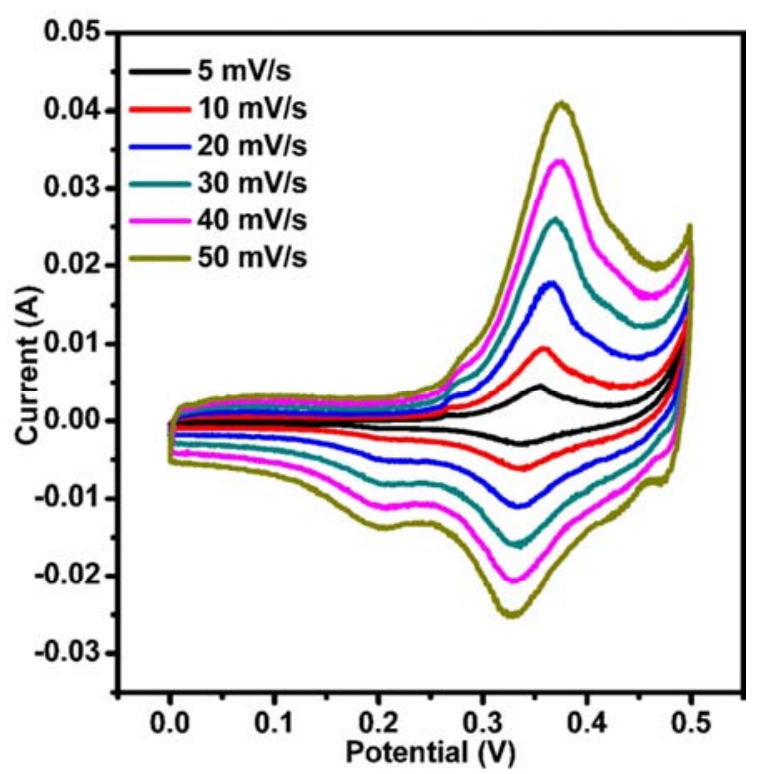

Figure 5. $\mathrm{CV}$ curves of $\mathrm{NF} / \mathrm{CO}_{3} \mathrm{O}_{4} / \mathrm{NiO}$ electrode at various scan rates.

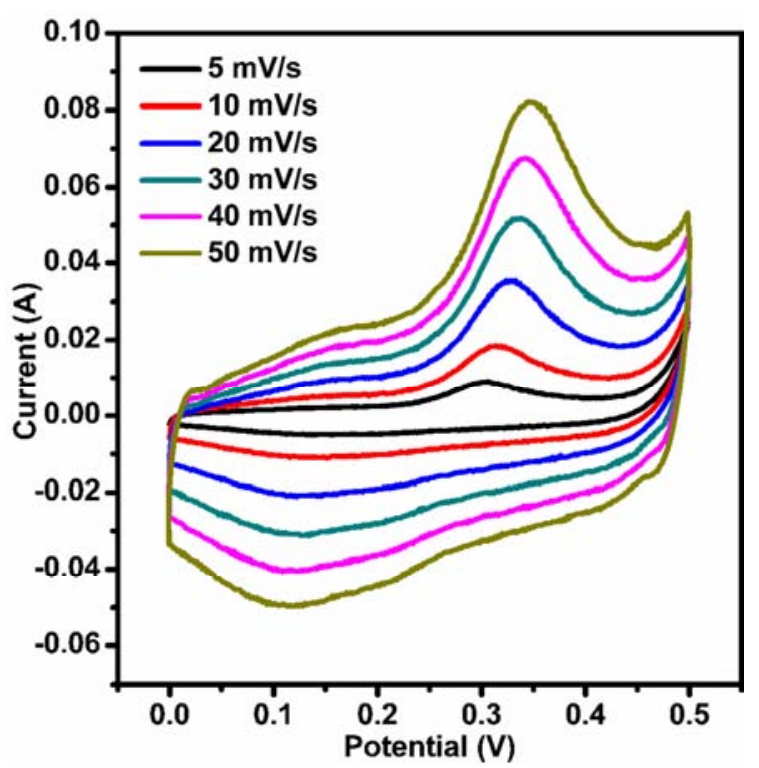

Figure 6. $\mathrm{CV}$ curves of $\mathrm{NF} / \mathrm{NiCO}_{2} \mathrm{O}_{4}$ electrode at various scan rates.

Figure 7 shows the comparison of galvanic charge-discharge (GCD) curves for the $\mathrm{NF} / \mathrm{CO}_{3} \mathrm{O}_{4}, \mathrm{NF} / \mathrm{Co}_{3} \mathrm{O}_{4} / \mathrm{Ni}(\mathrm{OH})_{2}$, $\mathrm{NF} / \mathrm{Co}_{3} \mathrm{O}_{4} / \mathrm{NiO}$ and $\mathrm{NF} / \mathrm{NiCo}_{2} \mathrm{O}_{4}$ electrode materials within a potential range from 0 to $0.45 \mathrm{~V}$ at $1 \mathrm{~A} / \mathrm{g}$. In our paper, all specific capacitances are calculated by the equation in the electrochemical measurement. The calculated specific capacitances for $\mathrm{NF} / \mathrm{Co}_{3} \mathrm{O}_{4}, \quad \mathrm{NF} / \mathrm{Co}_{3} \mathrm{O}_{4} / \mathrm{Ni} \quad(\mathrm{OH})_{2}$, $\mathrm{NF} / \mathrm{Co}_{3} \mathrm{O}_{4} / \mathrm{NiO}$ and $\mathrm{NF} / \mathrm{NiCO}_{2} \mathrm{O}_{4}$ are 202, 688, 992 and $239 \mathrm{~F} / \mathrm{g}$, respectively. As expected, the $\mathrm{NF} / \mathrm{Co}_{3} \mathrm{O}_{4} / \mathrm{NiO}$ electrode material exhibits higher specific capacitance than other materials due to its longer discharging time. Figure 8 and Figure 9 depict the GCD curves of the $\mathrm{NF} / \mathrm{Co}_{3} \mathrm{O}_{4} / \mathrm{NiO}$ electrode and $\mathrm{NF} / \mathrm{NiCo}_{2} \mathrm{O}_{4}$ electrode at current densities from 1 to $10 \mathrm{~A} / \mathrm{g}$ in the voltage window of $0-0.45 \mathrm{~V}$. The GCD curves were almost symmetrical, implying high coulombic efficiency of core-shell nanostructured material [42]. The specific capacitances of the 
$\mathrm{NF} / \mathrm{Co}_{3} \mathrm{O}_{4} / \mathrm{NiO}$ electrode are $992,968.9,948,907.4,844.1$ and $809.8 \mathrm{~F} / \mathrm{g}$ at the current densities of $1,2,3,5,8$ and $10 \mathrm{~A} / \mathrm{g}$, respectively. However, the specific capacitances of $\mathrm{NF} / \mathrm{NiCo}_{2} \mathrm{O}_{4}$ electrode are 238.7, 233.7, 226.6, 213.6, 198.7 and $187.7 \mathrm{~F} / \mathrm{g}$ from 1 to $10 \mathrm{~A} / \mathrm{g}$. Obviously, the specific capacitances of $\mathrm{NF} / \mathrm{NiCo}_{2} \mathrm{O}_{4}$ electrode are much lower than those of $\mathrm{NF} / \mathrm{Co}_{3} \mathrm{O}_{4} / \mathrm{NiO}$ electrode at the same current densities. That could attribute the enhanced performance of the $\mathrm{NF} / \mathrm{Co}_{3} \mathrm{O}_{4} / \mathrm{NiO}$ to the strong interaction between $\mathrm{Co}_{3} \mathrm{O}_{4}$ and $\mathrm{NiO}$.

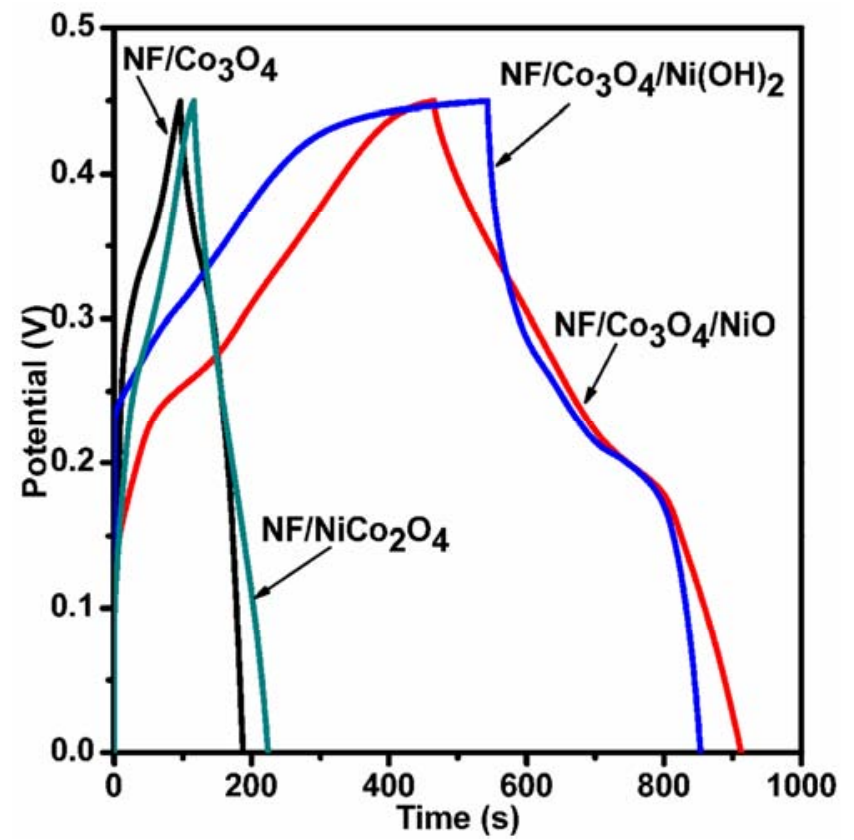

Figure 7. Galvanostatic charge-discharge curves of as-prepared electrodes at a current density of $1 \mathrm{~A} / \mathrm{g}$.

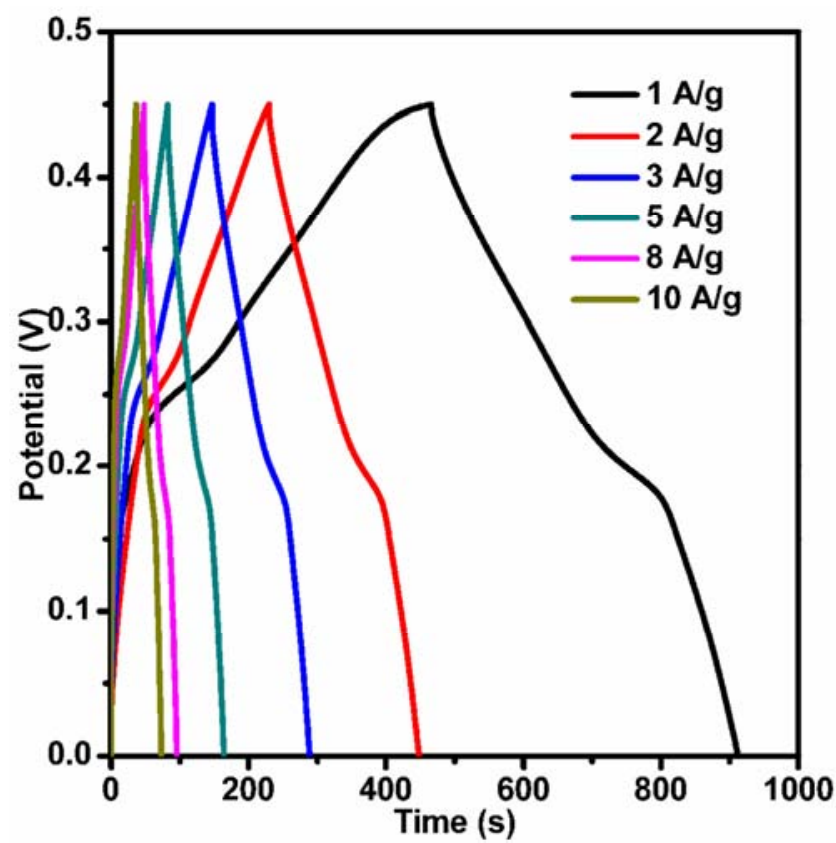

Figure 8. Charge-discharge curves of the $\mathrm{NF} / \mathrm{Co}_{3} \mathrm{O}_{4} / \mathrm{NiO}$ electrode at different current density.

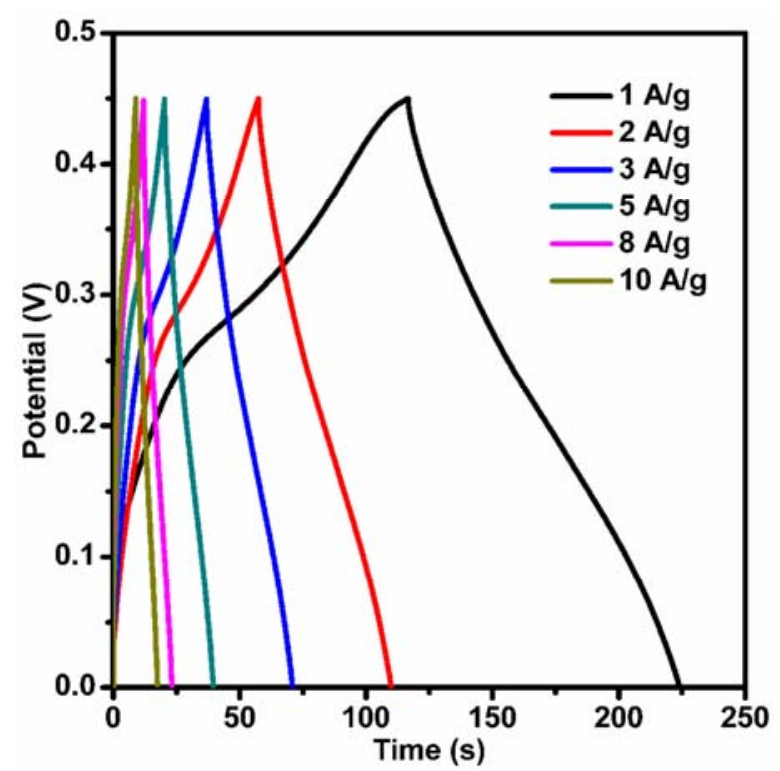

Figure 9. Charge-discharge curves of the $\mathrm{NF} / \mathrm{NiCO}_{2} \mathrm{O}_{4}$ electrode at different current density.

Good rate capability is also a crucial parameter to assess the potential application of supercapacitor [43, 44]. The relationship between $\mathrm{C}$ and current density for the four materials (their rate capability) was investigated Fig.10. The specific capacitances of $\mathrm{NF} / \mathrm{Co}_{3} \mathrm{O}_{4} / \mathrm{NiO}$ electrode at the same current density are much higher than those of other samples. The specific capacitance of $\mathrm{NF} / \mathrm{Co}_{3} \mathrm{O}_{4} / \mathrm{NiO}$ electrode changed from 992 to $809.8 \mathrm{~F} / \mathrm{g}$ maintaining about $81.6 \%$ of the initial capacitance as current density increased from 1 to $10 \mathrm{~A} / \mathrm{g}$, demonstrating the better rate capability of $\mathrm{NF} / \mathrm{Co}_{3} \mathrm{O}_{4} / \mathrm{NiO}$ electrode. It can be attributed to that the special 3D structure of $\mathrm{NF} / \mathrm{Co}_{3} \mathrm{O}_{4} / \mathrm{NiO}$ is beneficial to the transfer of electron and ion at the inter-face between the electrode and electrolyte [45]. This result further indicates the $\mathrm{NF} / \mathrm{Co}_{3} \mathrm{O}_{4} / \mathrm{NiO}$ material is a potential candidate as highperformance faradaic electrode materials.

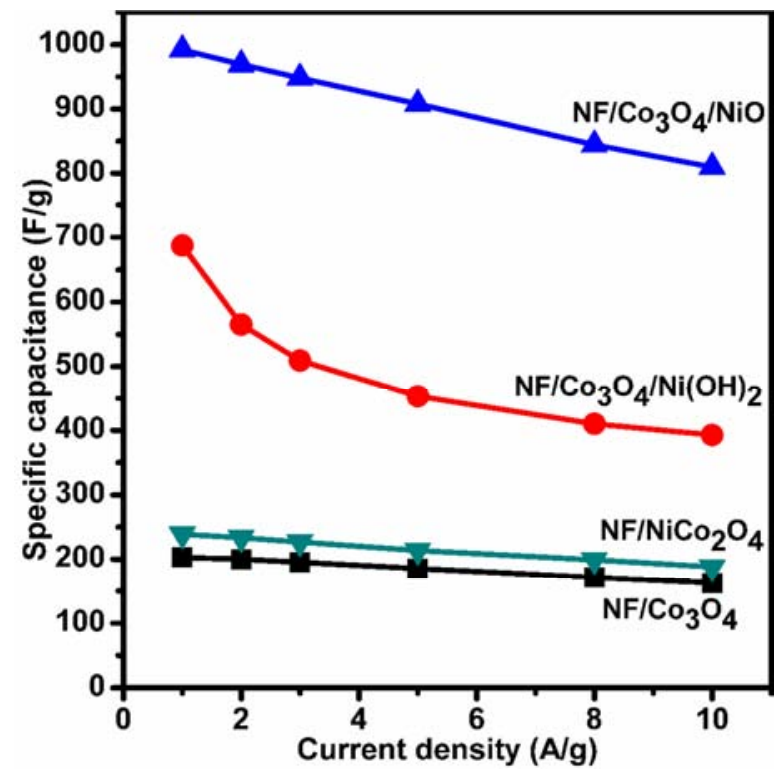

Figure 10. Specific capacitance of the as-prepared electrodes at different current densities. 
In order to investigate the long term cycling stability of electrodes, the electrodes are further continuously galvanostatic charge-discharge tested were at a current density of $10 \mathrm{~A} / \mathrm{g}$ in the potential window from 0 to $0.4 \mathrm{~V}$ for 2000 cycles (Figure 11). It is obvious that the $\mathrm{NF} / \mathrm{Co}_{3} \mathrm{O}_{4} / \mathrm{NiO}$, $\mathrm{NF} / \mathrm{Co}_{3} \mathrm{O}_{4}$ and $\mathrm{NF} / \mathrm{NiCo}_{2} \mathrm{O}_{4}$ electrodes display good stability. The capacitance retention of $\mathrm{NF} / \mathrm{Co}_{3} \mathrm{O}_{4}$ and $\mathrm{NF} / \mathrm{NiCo}_{2} \mathrm{O}_{4}$ are $89.5 \%$ and $93.8 \%$ after 2000 cycles. The capacitance of $\mathrm{NF} / \mathrm{Co}_{3} \mathrm{O}_{4} / \mathrm{NiO}$ increases gradually during cycling, so the capacitance is higher than the initial capacitance after testing 2000 cycles, demonstrating that the $\mathrm{NF} / \mathrm{Co}_{3} \mathrm{O}_{4} / \mathrm{NiO}$ electrode delivers excellent cycling performance.

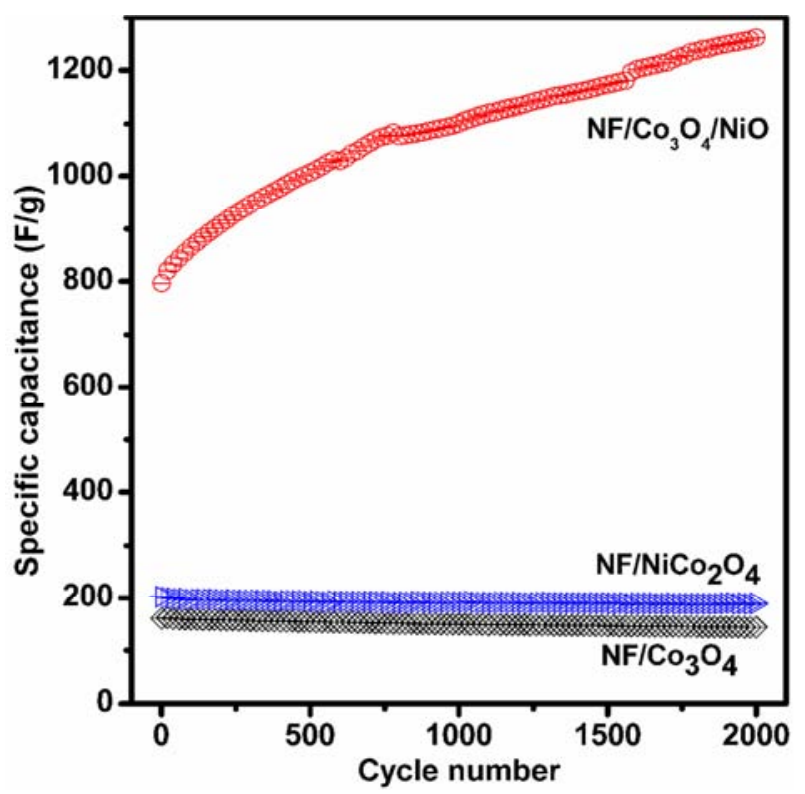

Figure 11. Cycling stability of the as-prepared electrodes at $10 \mathrm{~A} / \mathrm{g}$.

EIS analyses are believed as crucial complementary methods to traditional electrochemical measurements. The Nyquist plots are characteristic of being able to separate the charge transfer resistance and series resistance directly. Figure 12 depicts the resistance characteristics of $\mathrm{NF} / \mathrm{Co}_{3} \mathrm{O}_{4}$, $\mathrm{NF} / \mathrm{Co}_{3} \mathrm{O}_{4} / \mathrm{NiO}$ and $\mathrm{NF} / \mathrm{NiCo}_{2} \mathrm{O}_{4}$ electrodes, the inset is the enlarged view of grey box. All the Nyquist plots are similar, being composed of a semicircle at the high-frequency region, a linear section at the low-frequency region and a transition zone between two regions. The internal resistances $\left(R_{s}\right)$ of electrodes, represented by the high frequency intersection of the Nyquist plots in the real axis [46], are less than $1 \Omega$, which demonstrates the excellent electrical contact on the interfaces. The semi-circle diameter of the Nyquist plot is in connection with the interfacial charge transfer resistance $\left(\mathrm{R}_{\mathrm{ct}}\right)$ occurring at the electrode/electrolyte interface and double layer capacitance caused by Faradaic reactions, it is therefore called "Faradaic resistance", which is determined mainly by the electrical conductivity of the active electrode materials [47]. It is evident that the diameter of the Nyquist plot of $\mathrm{NF} / \mathrm{Co}_{3} \mathrm{O}_{4} / \mathrm{NiO}$ electrode is higher than that of $\mathrm{NF} / \mathrm{NiCo}_{2} \mathrm{O}_{4}$ and $\mathrm{NF} / \mathrm{Co}_{3} \mathrm{O}_{4}$ electrodes, demonstrating the $\mathrm{R}_{\mathrm{ct}}$ of $\mathrm{NF} / \mathrm{Co}_{3} \mathrm{O}_{4} / \mathrm{NiO}$ electrode is higher. This might be due to the presence of $\mathrm{NiO}$. In addition, in the low-frequency region, the slope of the straight line is referred to the Warburg resistance (W), which corresponding to the ion diffusion in the host material diffusive resistance of the electrolyte in the electrode surface [48]. In the Figure 12, the Nyquist plot of $\mathrm{NF} / \mathrm{NiCo}_{2} \mathrm{O}_{4}$ electrode is more vertical than $\mathrm{NF} / \mathrm{Co}_{3} \mathrm{O}_{4}$ and $\mathrm{NF} / \mathrm{Co}_{3} \mathrm{O}_{4} / \mathrm{NiO}$, which indicates that the abundant presence of Co can facilitate ion diffusion and electron transfer during the electrochemial reaction process which is in accordance with the previous reports $[49,50]$. In spite of the high impedance test results, the $\mathrm{NF} / \mathrm{Co}_{3} \mathrm{O}_{4} / \mathrm{NiO}$ as the electrode materials is promising for high-performance energy storage devices.

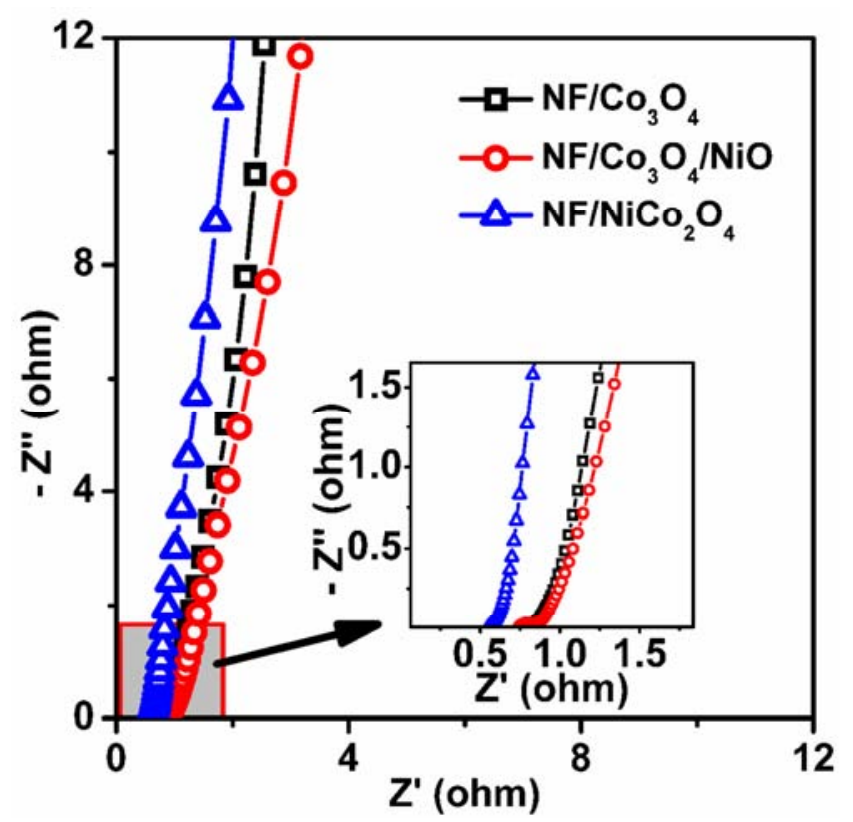

Figure 12. Nyquist plots of the as-prepared electrodes. The inset shows the enlarged view of grey box.

\section{Conclusion}

In conclusion, it presented a facile route for the synthesis of different morphology cobalt and nickel double layered oxides arrays on $\mathrm{Ni}$ foam substrate. As a result, the $\mathrm{NF} / \mathrm{Co}_{3} \mathrm{O}_{4} / \mathrm{NiO}$ electrode synthesized by two-step showed greatly higher capacitance (ca. $992 \mathrm{~F} / \mathrm{g}$ at $1 \mathrm{~A} / \mathrm{g}$ ) than the $\mathrm{NF} / \mathrm{NiCo}_{2} \mathrm{O}_{4}$ electrode obtained by one-step (238.7 F/g at $1 \mathrm{~A} / \mathrm{g})$. In addition, the $\mathrm{NF} / \mathrm{Co}_{3} \mathrm{O}_{4} / \mathrm{NiO}$ electrode exhibited good rate capability and high stability, which were due to the stable structure and the abundant presence of Co. Therefore, the present $\mathrm{NF} / \mathrm{Co}_{3} \mathrm{O}_{4} / \mathrm{NiO}$ coreshell arrays with remarkable electrochemical properties could be considered as potential electrode materials for next generation supercapacitors in high energy density storage systems.

\section{Acknowledgements}

We gratefully thank the financial support from Program for National Natural Science Foundation of China (51302062). 


\section{References}

[1] Y. Cheng, S. Lu, H. Zhang, C. V. Varanasi, J. Liu, Nano Letters, 12 (2012) 4206.

[2] G. Gao, H. B. Wu, S. Ding, L. M. Liu, X. W. Lou, Small, 11 (2015) 804-808.

[3] J. R. Miller, P. Simon, Science, 321 (2008) 651-652.

[4] M. Winter, R. J. Brodd, Cheminform, 35 (2004) 4245.

[5] Z. Niu, W. Zhou, J. Chen, G. Feng, H. Li, W. Ma, J. Li, H. Dong, Y. Ren, D. Zhao, Energy \& Environmental Science, 4 (2011) 1440-1446.

[6] C. Kim, B. T. N. Ngoc, K. S. Yang, M. Kojima, Y. A. Kim, Y. J. Kim, M. Endo, S. C. Yang, Advanced Materials, 19 (2007) 2341-2346.

[7] E. Tamburri, M. Angjellari, M. Tomellini, S. Gay, G. Reina, T. Lavecchia, P. Barbini, M. Pasquali, S. Orlanducci, Electrochimica Acta, 157 (2015) 115-124.

[8] G. Wang, L. Zhang, J. Kim, J. Zhang, Journal of Power Sources, 217 (2012) 554-561.

[9] A. K. Mondal, B. Wang, D. Su, Y. Wang, X. Zhang, G. Wang, Journal of the Chinese Chemical Society, 59 (2012) 12751279 .

[10] H. Zhang, G. Cao, Y. Yang, Energy \& Environmental Science, 2 (2009) 932-943.

[11] C. D. Lokhande, D. P. Dubal, O. S. Joo, Current Applied Physics, 11 (2011) 255-270.

[12] M. Mastragostino, C. Arbizzani, F. Soavi, Journal of Power Sources, 97 (2001) 812-815.

[13] Y. Xiao, S. Liu, L. Feng, A. Zhang, J. Zhao, S. Fang, D. Jia, Advanced Functional Materials, 22 (2012) 4051-4051.

[14] W. Du, R. Liu, Y. Jiang, Q. Lu, Y. Fan, F. Gao, Journal of Power Sources, 227 (2013) 101-105.

[15] X. C. Dong, H. Xu, X. W. Wang, Y. X. Huang, M. B. Chan-Park, H. Zhang, L. H. Wang, W. Huang, P. Chen, Acs Nano, 6 (2012) 3206.

[16] R. B. Rakhi, W. Chen, D. Cha, H. N. Alshareef, Nano Letters, 12 (2012) 2559.

[17] X. Zhang, W. Shi, J. Zhu, W. Zhao, J. Ma, S. Mhaisalkar, T. L. Maria, Y. Yang, H. Zhang, H. H. Hng, Nano Research, 3 (2010) 643-652.

[18] S. I. Kim, J. S. Lee, H. J. Ahn, H. K. Song, J. H. Jang, Acs Applied Materials \& Interfaces, 5 (2013) 1596.

[19] J. Kang, A. Hirata, L. Kang, X. Zhang, Y. Hou, L. Chen, C. Li, T. Fujita, K. Akagi, M. Chen, Angewandte Chemie, 125 (2013) 1708-1711.

[20] Z. Yu, B. Duong, D. Abbitt, J. Thomas, Advanced Materials, 25 (2013) 3302-3306.

[21] X. W. and, Y. Li, Journal of the American Chemical Society, 124 (2002) 2880-2881.

[22] G. Wang, L. Zhang, J. Zhang, Cheminform, 41 (2012) 797.
[23] B. Wang, X. He, H. Li, Q. Liu, J. Wang, L. Yu, H. Yan, Z. Li, P. Wang, Journal of Materials Chemistry A, 2 (2014) 12968-12973.

[24] Mathieu Toupin, Thierry Brousse, $\uparrow, \ddagger$ And, Daniel Bélanger, Chemistry of Materials, 16 (2004) 3184-3190.

[25] Y. Si, T. Ren, B. Ding, J. Yu, G. Sun, Journal of Materials Chemistry, 22 (2012) 4619-4622.

[26] H. Y. Lee, J. B. Goodenough, Journal of Solid State Chemistry, 148 (1999) 81-84. L. Su, Y. Wang, Y. Sha, M. Hao, Journal of Alloys \& Compounds, 656 (2016) 585-589.

[27] Z. Fan, J. Chen, K. Cui, F. Sun, Y. Xu, Y. Kuang, Electrochimica Acta, 52 (2007) 2959-2965.

[28] T. Liu, Y. Li, G. Quan, P. Dai, X. Yu, M. Wu, Z. Sun, G. Li, Materials Letters, 139 (2015) 208-211.

[29] K. Xu, R. Zou, W. Li, Y. Xue, G. Song, Q. Liu, X. Liu, J. Hu, Journal of Materials Chemistry A, 1 (2013) 9107-9113.

[30] K. Wang, Z. Zhang, X. Shi, H. Wang, Y. Lu, X. Ma, Rsc Advances, 5 (2014) 1943-1948.

[31] H. Jin, T. Okamoto, M. Ishida, Energy \& Fuels, 12 (1998) 1272-1277.

[32] Y. Zhang, J. Wang, L. Yu, L. Wang, P. Wan, H. Wei, L. Lin, S. Hussain, Ceramics International, (2016).

[33] F. Wang, J. Wang, H. Ren, H. Tang, R. Yu, D. Wang, Inorganic Chemistry Frontiers, 3 (2016) 365-369.

[34] J. M. Won, S. H. Choi, Y. J. Hong, N. K. You, Y. C. Kang, Scientific Reports, 4 (2014) 5857.

[35] G. Zhang, L. Yu, H. B. Wu, H. E. Hoster, X. W. Lou, Advanced Materials, 24 (2012) 4609-4613.

[36] H. Han, B. Guan, B. Xia, W. L. Xiong, Journal of the American Chemical Society, 137 (2015) 5590.

[37] Y. Huang, Y. E. Miao, H. Lu, T. Liu, Chemistry, 21 (2015) 10100 .

[38] B. Cui, H. Lin, J. B. Li, X. Li, J. Yang, J. Tao, Advanced Functional Materials, 18 (2010) 1440-1447.

[39] T. Y. Wei, C. H. Chen, H. C. Chien, S. Y. Lu, C. C. Hu, Advanced Materials, 22 (2010) 347-351.

[40] X. Gong, J. P. Cheng, F. Liu, L. Zhang, X. Zhang, Journal of Power Sources, 267 (2014) 610-616.

[41] Z. Zhang, H. Zhang, X. Zhang, D. Yu, Y. Ji, Q. Sun, Y. Wang, X. Liu, Journal of Materials Chemistry A, 4 (2016).

[42] J. H. Zhong, A. L. Wang, G. R. Li, J. W. Wang, Y. N. Ou, Y. X. Tong, Journal of Materials Chemistry, 22 (2012) 5656-5665.

[43] F. Gao, J. Qu, Z. Zhao, Q. Zhou, B. Li, J. Qiu, Carbon, 80 (2014) 640-650.

[44] X. Meng, M. Feng, H. Zhang, Z. Ma, C. Zhang, Journal Of Alloys And Compounds, 695 (2017) 3522-3529.

[45] X. Xie, L. Gao, Carbon, 45 (2007) 2365-2373.

[46] J. Xu, S. Gai, F. He, N. Niu, P. Gao, Y. Chen, P. Yang, Dalton Transactions, 43 (2014) 11667-11675. 
[47] K. Adib, M. Rahimi-Nasrabadi, Z. Rezvani, S. M. Pourmortazavi, F. Ahmadi, H. R. Naderi, M. R. Ganjali, Journal of Materials Science Materials in Electronics, 27 (2016) 4541-4550.

[48] L. Xie, Z. Hu, C. Lv, G. Sun, J. Wang, Y. Li, H. He, J. Wang, K. Li, Electrochimica Acta, 78 (2012) 205-211.
[49] V. Gupta, S. Gupta, N. Miura, Journal of Power Sources, 175 (2008) 680-685.

[50] J. Kang, A. Hirata, L. Kang, X. Zhang, Y. Hou, L. Chen, C. Li, T. Fujita, K. Akagi, M. Chen, Angewandte Chemie, 125 (2013) 1708-1711. 